Curriculum Resources:

More Than the Sum of Books and A-V

by Ken Haycock

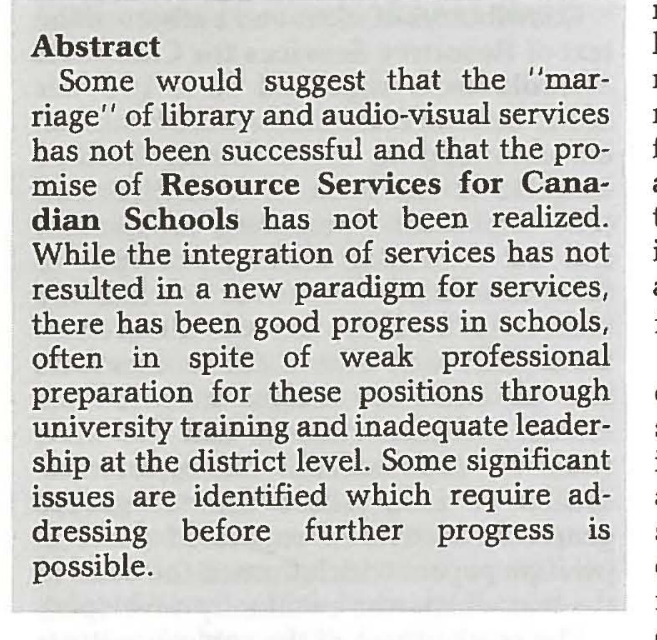

Introduction

of the failed marriage of school libraries

and educational media for this special
issue of CJEC I couldn't help but wonder if this was still an issue, and if so why? I the integration of "library" and "av" the Is current reality closer to the means and methods we preferred in the 1960 s rather
than the 1980s? Are we really making very little progress in entering the educato learning resources, undergirding the
educational enterprise? educational enterprise?

Thave perhaps a rather simplistic view of the place of curriculum resources in
the teaching/learning process. It seem Ken Haycock is acting manager of elementary/ secondary education for the bia, with responsibilities for working curriculum and professional developmen programs for 3,000 teachers and ad ministrators. He was previously coor
dinator of library services and superviso of instruction K-12 for the board's 110 school resource centers and district ser-
vices. Mr. Haycock is past president of vices. Mr. Haycock is past president of Association. reasonable to me that each school should materials, including books, periodicals, maps and other print materials as well as
filmstrips, slides, recordings and other audiovisual materials. One would hop ing accepted criteria for excellence and appropriateness and would be organize for effective use by teachers and students.
This scenario is not at all unrealistic; in selection and organization of materials in individual locations, this is the case in
almost every school in the country. In called school libraries, in others school ched in educational thinking and programs as a "good thing".

(hems reasonable that each in charge of the maintenance and effective exploitation of this collection
Presumably, should logic prevail, this in dividual would have additional qualifications in the essential areas of administr tion, selection, organization and effectiv use of learning resources, recognizing
that courses in such subjects are fairly teacher will plan programs with classroom colleagues which integrate the
skills necessary for students to handle information logically and rationally, pa ticularly in those essential areas of pro-
cessing and using information. Th cessing and using information. Thro-based learning is effective for
resour number of reasons: there is clarity of communication between the teachin
partners; skills are clearly specified for eaching and evaluation; the subject co vext and classroom framework are same group of youngsters.

personnel factor has not entered that some parts of the some parts of the country. Most schools
do have the collections and facilities deed, without debating the quality of almost every school in the country.
some jurisdictions these collections are readily available and do add to qualific use to take place, we know that this vious to the student; two teachers an
selected resources are available to the some have staff to manage the collection;
fewer have professional staff to ensure that the collection is used; still fewer have the qualified professional staff trained in this exploitation; and still fewer again
have the qualified professional staff, by have the qualified professional staft, by
whatever definition, who are committed to effective use through integration with instructional programs and cooperative program planning and team teaching. review of the direction of library and media services which resulted in Resource Services for Canadian
Schools. I recall quite clearly the anSchools. I recall quite clearly the anparadigm of resource-based learning, not only integrating library and audio-visual services but in fact creating a better apuse of learning resources in the school. school resource cecommended for the ing resource teacher who would work logically, effectively and persistently serious discussion at the time of calling this individual an "animature" to further define expectations for change
Where did we go wrong?

What is the Problem?

Has there really been an unhappy marriage of school libraries and educational more appropriately resource centre, is a including print and audio-visual
materials. Few libraries include only materials. Few libraries include only
printed materials yet stereotypes persist printed materials yet stereotypes persist
that libraries are for books. Perhaps the marriage is secure but the offspring not
yet produced; the offspring being that new paradigm or philosophical construc of the place of resource-based learning in librarian (or learning resource teacher, if you will) in fostering it.

Terminology

library common link between school specialists is of course teaching and learning; this link is even more obvious be ween members of either group and their alienate ourselves and our services from this mainstream by creating "barriers
through jargon? "Perhaps "learning
resource teacher "was too advanced for resource teacher "was too advanced for
its time and was confused with special education teachers in some jurisdictions.

VOLUME 14, NUMBER 3, 1985 adopted in 1982 , does at least include librarians and learning resource
reference to the teaching component but reference to the teaching component; $b$
why "librarian" when referring to the novative, effective teacher? Why
"library" when referring to the school's collection of learning resources, $p$ sion of a library from experiences outside of schools? Why "library skills" when "information skills" designate
clearly the function envisioned?

Qualifications

The policy statement of the Canadian School Library Association on Qualifica-
tions for Teacher-Librarians includes nine areas of competence. Throughout the document the terms "learning materials" and "learning resources" are
used, yet in the reactions from leaders in instructional technology the proposed oriented and library-oriented. The only rationalization for this problem was the
rather obvious bias with which the doc rather obvious bias with which the docu-
ment was being read lif it's coming from ment was being read (if it's coming from
the CSLA insert "book" whenever you see "learning resources'). Another exam-
ple, from leaders in both sectors, pointed o the lack of mention of newer techwas, yet the document does not say that information is to be organized manually, or that information retrieval is to be
limited to printed pages. We all have ou biases and we recognize this, but occa-

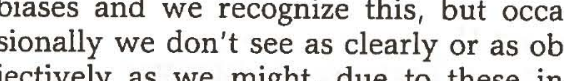
jectively as we might, due to these in

The policy statement does specifically

point to the need for competence in the
following nine areas: administration of the learning resource program

" selection of learning resources acquisition, organization and circula-
tion of learning resources reading, listening and viewing

guidance design and production of learning

promotion of the effective use

learning resources and services
cooperative program planning and

teaching

* professionalism and leadership

siderable consultation with leaders in the

field. There would appear to be no issue
with the areas outlined. One need ask

hen if these areas are being developed in
he programs which educate teacher-

When integration of materials and ser-
vices is so prevalent at the school level why is it so singularly lacking at the university level? Can we say with con-
fidence that graduates of these prograts can articulate information skills, including critical listening and viewing
skills, in a developmental continuum, and skills, in a developmental continuum, and
that they not only understand the need for working with classroom teachers, bu for working with classroom teachers, but
also have the skills necessary to develop and strategies for effective team planning d teaching? Decidedly not.

What kinds of experiences are being provided to candidates in these programs strategies for developing an integrated learning resources program? And, if the professional aren't providing adequate committed to staff development programs to compensate for this?
This issue becomes even more This issue becomes even more
prevalent at the district level with probackground in teaching but have significantly different professional educavisual services, resulting in differentiofessional socialization, associations and networks.

District Networks

Major issues in approaches to service library and audio-visual services can almost invariably be traced to the way in services designed to support, connect and the district or are district services designed to serve individuals in schools directand their coordinators, still focus on dif ferences in philosophy and approach of teacher-librarians and audio-visual specialists while refusing to draw those cohesive, unified system which recagnizes differences but supports programs with the best that the total system has to offer. Teachers should be able to look to their school resource centre to serve to a larger system in a planned, efficin-

Medium or Message?

I suppose there are still those who focus
on the medium, whether it be microcom-

CANADIAN JOURNAL OF EDUCATIONAL COMMUNICATION puter software, films or children's books, medium for the specific teacher/learning design. And there are without recognizing the strengths an weaknesses of each and their often uni-
werthont que purpose. This, it seems to me, has literature or video production than a sadly lacking ment and the cohesion necessary to foster a school-based approach to informatio handling, which not only recognizes, bu tyles to attain the same objectives.

Whose Skills? Whose Program? Teacher-librarians are focusing mor The in the curriculum. There and their , however, that the skills of effective stening and viewing are not being adgnificance. More support is needed her faculty and district coor-
in terms of teachin out reaching developing the ability of the teacher. to instructional programs. Again, ignorance of the abilt ately, recognition of these needs as priority, are equally applicable. New Technology

Perhaps the differences among learnin apparent as opportunities exist for the exremists to make their case for or agains microcomputers. The "bookies" play heir own computer competence (le (leadership), while the "hackers" fondly at the equipment and develop computer programs. These are extreme we need more professionals who are comDiffalls of current applications of new 作

While it is feasible to sit around and Continued on page 22. 
debate the issue of school libraries an trivializes the major issues. While we bemoan the lack of integration of differen types of learning resources, particularly the media and their collection and organization. In an information society
more time and energy has to be devoted we have available to us in effective in structional programs to teach youngster how to process and use information. To do that, we go right back to the pro mise of Resource Services for Canathe program a role for a clear aim for sonnel which is clarified and focused good programs to prepare this staff, a
district approach to coordination of resource centres and their development programs which focus on program development and enhancement, and a
commitment to well-designed, wellintegrated resource based learning programs for young people. This is really the least we can do with any degree of profes-
sonal competence and respect.

\section{MISSION POSSIBLE}

ontinued from page 9

The standards contain both quantitative sent a compromise between 'what should be' as expressed in the literature and sent economic climate." It is intended that they be interpreted as minimum rather than desirable expectations.
The inclusion of quantitative standar or school library collections, staffing and they are seen by schools exceeding them as too low, and by those at the other end of the spectrum as impossible to attain. a urisdictions would have some difficulty phasing in the standards over a $3-5$ year period.
Following are the standards for libra

Library Staf

Professional direction is critical to the an effective program.

Professional direction may be proa) By a full-time teacher-librarian on the school staff.

time library and part-time teaching
tim assignment.
By a teacher-librarian serving more
than one school in the district. d) By supervision by a school district
(central office) teacher-librariane) By cooperative agreement with Sy cooperative agreement with
regional library system f) Where no teacher-librarian is available, by the principal and
teaching staff of the school. Note: i) The minimum qualifications of a
teacher-librarian should include teacher certification and successful teaching experience along with university credits in
at least eight half courses in
librarianship and instructional technology.
ii) Active participation on the part of the principal and teachers in
the implementation of library program must increase as teacher-librarian time is
decreased.

Qualified technical/clerical support should also be provided.
Professional and technical/clerica support should meet or exceed the $\begin{array}{lll}\text { following standards: } & \\ \text { School Teacher- Technical }\end{array}$ Librarian Clerical $\begin{array}{lcr}150 \text { Students } & & 1 / 2-1 \\ 300 \text { Students } & 1 / 2 & 1 / 2-1 \\ 500 \text { Students } & 1 & 1 \\ 750 \text { Students } & 1 & 1^{1 / 2}-2\end{array}$ 150 Students

1000 Students

$11 / 2-2$

$1 / 2-2$
2

The School Library Collection

the major collection should support tional program and represent a balanced range of student interests and needs, including the appreciation of

The size of the basic collection should enrollment served, the number of grades taught in the school, the tymber and types of instructional pro mams, and accessibility of relevant
materials through regional coopera-
tion, networking and interlibrary loan rranemerting and ing The basic library collection for a
chool of 250 students should include. print and nonprint material

magazines 4,000 titles
20 pamphlets, pictures... to meet film/video, etc. . . from Regional Fils Centre, District IMC, ACCESS
Alberta Educational Communications

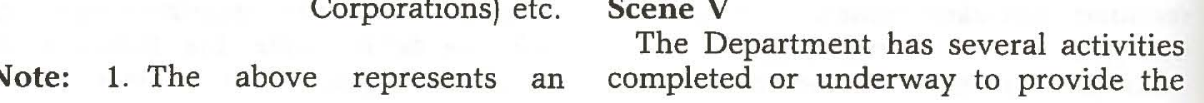

VOLUME 14, NUMBER 3, 1985

college and university libraries.
congen

The reference collection should

Schools offering programs in both English and languages
other than English, should increase the basic collection to inmaterials (print and nonprint) to support instruction in the
language|s offered. Selection criteria for the library collection should be consistent
with:
a) Guidelines for tolerance and statement. c) Canadian content priorities.
d) Identified library program f) Information from recognized chase of new materials, supplies and equipment lif equip-
ment is not provided for in the budget categoryl The budget realize library program goals
and objectives. It should be recognized that smaller schools and schools offering programs a higher than average evaluations. Added to these priorities
for $1985 / 86$ is school libraries. The grants provide for $\$ 9.00$ per pupil in
grades one through twelve, and $\$ 5.40$ per early childhood services student.
The guidelines for this funding focus proved classroom instruction. areas have been identified by Alberta Education for additional funding. These may vary from year to year. For $1985 / 86$, additional support will be
given for the enhancement of school given for the enhancement of school
library learning resource collections. These funds will be allocated to school boards on the basis of $\$ 10.00$ per stu-
dent or $\$ 1000.00$ per school which ever is greater. The funds are to be aption for, the funds normally allocated for the development of library collec-
tions. In June 1986, boards will be extions. In June 1986, boards will be ex-
pected to make an interim report of pected to make an interim report of ding, with a final report in June, 1987.
School boards will be required to have on activities which will result in im-

documents on file that are consisten
with the new library policy; a plan for priority needs for collection develop. policy aproved by the and selection The 4500 responses to the questionnaire are a testimony to the commitment rvices - from the leading man, David King, Minister of Education, to the 'cas vincial library association, strongly sup-

ported by parents.
Educators have given a standing ova Education. Curtain calls are inevitable. ption of this model will be available to all Alberta schools, spring Throughout discussions related to the made to the need for inservice educational programmes for teacherministrators. In 1984, Alberta Eduction etsablished a new fund for teach priority areas of computer literacy

include at least one
general encyclopedi a) Guidelines for tolerance and
understanding.
b) Controversial issues policy e) Needs identified by students should be allool library budget should be determined on the in English as well as languages

Harry Newsom (from his base in Ed-
nonton and later in Kamloops) worked monton and later in Kamloops) worked situated in Winnipeg, Regina, Calgary, and London. Meetings of the nationa
committee were held in Edmonton, Win
STANDARDS REVISITED

continued from page 5. Edmonton and
located in Toronto, I related with the
groups in St. Catharines, Toronto, Guelph groups in St. Catharines, Toronto, Guelph
and London. Meetings of the national nipeg and Toronto. These had to be kept to a minimum because of the costs involved. The principal coordination of the
work of the various groups in western work of the various groups in western
and central Canada was achieved by frequent meetings between Harry Newsom
and me. Most of these work sessions were held in Winnipeg, although some were in Oronto and Kamloops.

Neither the Canadian School Library
Association nor the Educational Medi Association of Canada (or its successor,
the Association for Media and the Association for Media and
Technology in Education in Canadal had he financial resources to support ac-
tivities on such a large scale. The prepara tion of the manuscript might well have
been impossible had it not been for the been impossible had it not been for the
generous grant of $\$ 12,000.00$ by the World Book Encyclopedia of Chicago and Toronto. With that assistance it was possi-
ble to pay for the postage, telephon charges and travelling expenses that were We have now come full cycle in 1985 and it is again time to consider revision of vices for Canadian Schools. We have today the same two options which we had in 1971: two separate books (one each
published by C.S.L.A. and A.M.T.E.C.) or a single set of standards published by the two associations jointly.
The convenience is tempting for each ment of the true faith from its point of view, without the bother of developing a
consensus with others in the field. It would be the easier way to go and more conducive to ego trips, both corporate and personal. It would, however, be a derelic tion of duty.

The dangers which we face as librarians and media specialists, we face in com-
mon. When reduced funding undermines the provision of learning mateirals, all are affected. The negativism of the "back to
basics" revisionists makes no distinction between us. Neither books nor films are safe from witch hunts. We are attacked in common and we must defend ourselves together. Any revision or the replacement
of the present standards must be a joint of the present standards must be a joint
A.M.T.E.C. - C.S.L.A. project. The central issue is whether we want to
tocommed unified standards or to

CANADIAN JOURNAL OF EDUCATIONAL COMMUNICATION
REFERENCES

school libration. (1984). Alberta school libraries

(1984). Policy, guidelines, procedures and stan-
dards for school libraries in
Alberta. Edmonton, AB: Author. retrogress to separate sets of recommen-
dations. It is not whether it should be ingle larger book or a series of smaller oces dealing with various particularities d herring. Either comprehensive or odular publications can be produced options is to publish two separate books or, if we go the modular route, ten or ach other for sales, subtly contradicting nd lessening one another's credibility. Our other option is to develop a consensus and to speak with united conviction and doubled authority to those who need ing materials in all media and to be The members of the Association for Cedia and Technology in Education in Library Association have an obligation to present the case for the acquisition, prouction and utilization of learning materials in every medium, not com ne association at the expense of the other, but cooperatively in a bond of and librarians alike, the means of obtaindangers and of achieving greater success in common endeavors. hown how to use them effectively. 